\title{
"Empirical Study on Corporate Governance Performance Index with Reference to Selected Corporate Sectors"
}

\author{
Dr. M. Sakthivel Murugan \\ Professor-in-Charge, D.B.Jain College, Chennai
}

*Corresponding Author: Dr. M. Sakthivel Murugan, Professor-in-Charge, D.B.Jain College, Chennai, India

Abstract: Corporate governance succeeded in attracting a good deal of public interest (Pankaj Sharma, 2004) because of its apparent importance for the economic health of corporations and society in general. Different people have come up with different definitions that basically reflect their special interests in the field.

The Corporate Governance Index is practiced by various corporate organizations in India. This index is developed by the ICSI, New Delhi in its Chartered Secretary Journal. The first article was published in Chartered Secretary Journal July 2003 using various CG Parameters and related aspects like board and management structure, Board composition, Board Committees, Transparency, shareholders claim satisfaction, financial information and CSR etc. What types of corporations have disclosed more corporate governance information in the annual reports?

It is also helps in identifying the extent of disclosure levels by various organizations and measuring the size of corporations across major economic sectors.

\section{CONCEPT OF CORPORATE Governance}

Corporate governance is typically perceived as an academic literature which is dealing with "problem that results from the separation of ownership and control" (Fernando AC, 2009).Thus the CG would be viewed from this perspective on: Defining the internal structure and specifying the rules of the board of directors; establishing independent audit committees; mechanism for disclosure of information to shareholders and creditors; and, control of the management (Figure1.1 explains how a corporation is structured.

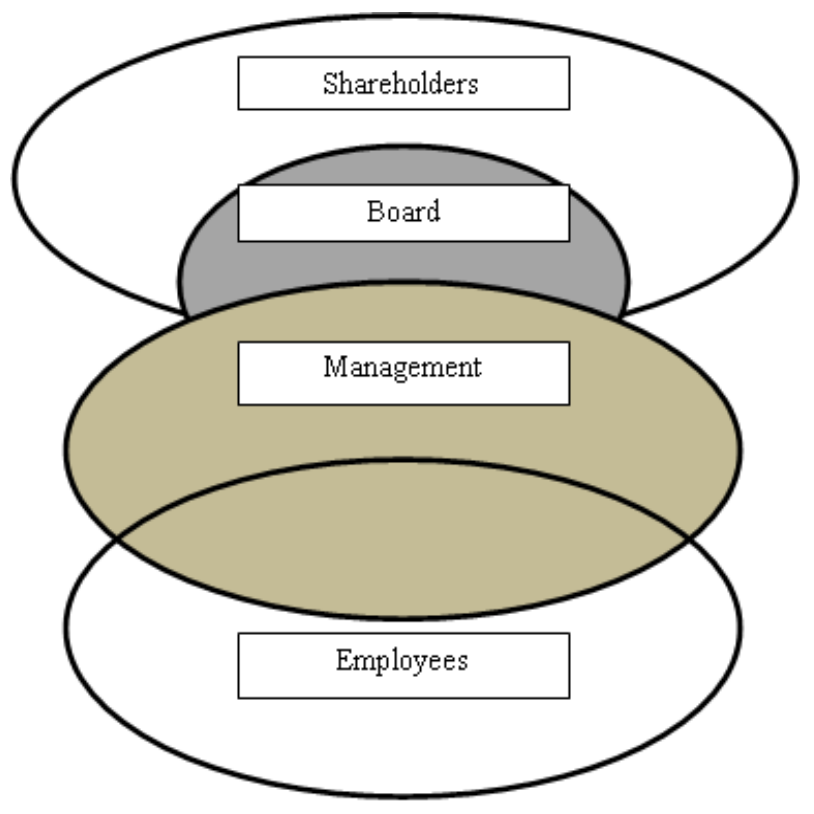

Figure1.1. Separation of ownership and management

Source: Corporate Governance - Principles, Policies and Practices by A.C Fernando 
Corporate governance succeeded in attracting a good deal of public interest (Pankaj Sharma, 2004) because of its apparent importance for the economic health of corporations and society in general. Different people have come up with different definitions that basically reflect their special interests in the field. Some of the important and comprehensive definitions of corporate governance are mentioned as under:

The father of corporate governance Sir Adrian Cadbury defines corporate governance as "the system in which companies are directed and controlled".1Board of Directors are responsible for the governance of their companies. The primary role of shareholders in governance is to appoint, reappoint or remove the directors and the auditors and ensure that an appropriate governance structure is in place. The responsibilities of the board include setting the company's strategic aims, supervising the management team and providing the leadership to put them into effect, and reporting to shareholders on their stewardship. The board's actions are bound by regulations, laws and the shareholders in general meetings."

\section{CONCEPT OF CORPORATE GOVERNANCE INDEX [CG]}

The concept of CG is shifting of objective from profit maximization to enhancing shareholders' value through transparent, fair and efficient manner by creating suitable policies of organization.

Several studies have investigated various determinants of corporate mandatory and non-mandatory disclosure (voluntary) practices. There are various corporate governance factors that may influence disclosure practices of listed entities. Some of these factors include :Audit committee, CEO duality, Size of the Board of Directors, Management holdings, Block shareholders' holding, Board Structure, CSR, Safety \& Health, Sustainability reporting, Risk Management, Internal control systems and their adequacy, Investors' Grievance Committee, Whistle blower policy and Independent Auditors' Report etc.

A Corporate Governance Disclosure Index is built based on the above mentioned aspects of governance structure. This index is used as a proxy measure of the effectiveness of the corporate governance mechanism and also to understand extent of disclosure level of information in the annual reports. Moreover, it is also helps in identifying the extent of disclosure levels by various organizations and measuring the size of corporations across major economic sectors.

The Corporate Governance Index is practiced by various corporate organizations in India. This index is developed by the ICSI, New Delhi in its Chartered Secretary Journal. The first article was published in Chartered Secretary Journal July 2003 using various CG Parameters and related aspects like board and management structure, Board composition, Board Committees, Transparency, shareholders claim satisfaction, financial information and CSR etc. What types of corporations have disclosed more corporate governance information in the annual reports?

It is also helps in identifying the extent of disclosure levels by various organizations and measuring the size of corporations across major economic sectors.

\section{Following are the methodology for determining for measuring an index of corporate governance parameters using score method.}

The formula for computation of CG Index given below:

$$
\text { CG Index }=\underset{\text { Expected Score }}{\text { Actual Score }} 100
$$

Given below is an example of using CG Index Formula.

\footnotetext{
${ }^{1}$ Report of the committee on the Financial Aspects of Corporate Governance, given by Sir Adrian Cadbury
} 
"Empirical Study on Corporate Governance Performance Index with Reference to Selected Corporate Sectors"

Table. Disclosure about Agenda circulated among Board

\begin{tabular}{|c|c|c|c|c|}
\hline Company & Disclosed & Not disclosed & Actual Score Points & Expected Score Points \\
\hline RIL & Yes & & 1 & 1 \\
\hline Wipro Ltd & Yes & & 1 & 1 \\
\hline Infosys & Yes & & 1 & 1 \\
\hline ITC & Yes & & 1 & 1 \\
\hline HDFC & & No & 0 & 1 \\
\hline ICICI Bank & & No & 0 & 1 \\
\hline HLL & & No & 0 & $\mathbf{7}$ \\
\hline Total & & & $\mathbf{4}$ & 1 \\
\hline
\end{tabular}

CG Index $=\frac{4}{7} \times 100$

Based on the data collected through questionnaire, the researcher has proposed to develop various tables and then 1 point will be given to the each disclosed items and 0 points for non-disclosed items. On this basis the researcher has developed corporate governance disclosure index with the following formula.

Corporate governance index $=$ Total disclosure of units $\mathrm{x} \quad 100$

Maximum disclosure of corporate governance

(Source: Chartered Secretary Journal)

The researcher also propose to classify various company in the group as

\section{A - High Corporate Governance index companies \\ B - Moderate Corporate Governance index companies \\ C - Low Corporate Governance index companie}

The aim of this paper to focus on developing Corporate Governance Index in Select Corporate Companies.

\section{RESEARCH METHODOLOGY}

It is an empirical study, so the researcher has followed scientific approach to design the research methodology for investigation. For this study researcher has used primary data and secondary data as a source of information.

\subsection{Sources of Primary Data}

The study is based on perceptual responses of professionals with regard to organizational perceptions and effectiveness on corporate governance practices. For this purpose, data were collected through structured questionnaire by emails, post and field survey.

\subsection{Sources of Secondary Data}

For the purpose of secondary data the researcher has used published Annual Reports, websites and other publications of sample companies. For sampling the researcher has used stratified sampling technique. The number of corporate sector is very large and it is beyond the capacity of individual researcher to conduct the study with census. Hence the researcher has considered the survey conducted by "Business Today", published in November 2013 for the selection of sectors. There are 24 sectors in the Top 500 companies in terms of highest market capitalization. Out of 24 sectors the researcher has selected 5 sectors randomly. These are 1) Overall Top 10 companies, 2) Top 10 IT companies, 3) Top 10 Pharma \& Healthcare\& Healthcare companies, 4) Top 10 Manufacturing companies, 5) Top 10 Automobile companies. Each sector has 10 companies. Thus the researcher has taken total of 50 companies for the study.

\section{Construction Of A Model Of Corporate Governance}

All Indian listed companies to file with SEBI the corporate governance compliance report along with financial statements. Therefore there is a need to develop a methodology for measuring voluntary corporate governance disclosure practices, as mandatory disclosure is already taken care by Clause 
49. In this study corporate governance-related disclosure developed under 52 questions categorizing into Board structure, Board process, Transparency \& Disclosure, Safety health, CSR Initiatives, Risk Management, Internal control systems \& Adequacy, Board Committees, Investor Grievances Committee, Whistle Blower Mechanism and Independent Auditor's report. In this study, only the annual report information is used for calculating corporate governance and disclosures (CGD) score of companies. The annual reports of the selected 50 companies were examined for the financial year 2014-15. In order to arrive the overall disclosure score annual reports of each company under study were carefully scrutinized for the presence of specific items under the above mentioned categories. One point is award when information on an item is disclosed and zero otherwise. On this basis the researcher has developed corporate governance disclosure index with the following formula.

\section{Corporate Governance Disclosure (CGD) score formula}

Corporate governance index $*$ Total disclosure $\mathrm{x} 100$

Maximum disclosure *

(Source: Chartered Secretary Journal)

In Corporate Governance structure and disclosures, the question immediately comes to mind is what is the standard and quality of governance that has been achieved by various Companies? Hence the researcher analyzed the total actual scores obtained for corporate governance $(\mathrm{CG})$ practices in respect of 52 parameters for all sample companies and classified into rank as per below table.

Table1. Ranking of CGD Score

\begin{tabular}{|c|c|c|}
\hline CGIndexScores & Category & Rank \\
\hline Above $82 \%$ & Best CG Index companies & 1 \\
\hline $74 \%-81 \%$ & Moderate CG Index companies & 2 \\
\hline Lessthan73\% & Below average CG Index companies & 3 \\
\hline
\end{tabular}

Source: Computed data

From the above table, it can be observed that the researcher classified the corporate index scores into three categories based on the range values. It implied the first category is with less than $73 \%$, second category ranges from $74 \%$ to $81 \%$ and the largest category is with the corporate governance index scores above $82 \%$. The higher corporate scores implies the best corporate governance followed by moderate and below average. The main aim of the corporate governance is to organize the companies very well in the future and also to ensure their growth. This shows that the corporate governance should have the impact on the financial performance of the companies which is clearly noted in the following section.

\section{IMPACT OF CORPORATE GOVERNANCE ON FINANCIAL PERFORMANCE OF THE COMPANIES}

In the present study, the researcher has attempted to link the corporate governance practices with financial performance of the selected sample companies. For this, the researcher has selected 12 different variables of financial performance which are identified as dependent variables to understand the impact of corporate governance parameters on them. These included, Total Turnover (TT), Profit after tax (PAT), Return on Asset (ROA), Debt-Equity Ratio (D/E ratio), Earnings per share (EPS), Total Debt (TD), Total Assets (TA), Market Capitalization (M-Cap), Interest Coverage Ratio(IC ratio), Return on Capital Employed (ROCE), Tobin's Q (TQ) and Share price. Thus the financial performance score arrived by adding the scores of 12 financial variables for individual companies with the formula viz., Total Actual score divided by the total Expected score. Thus derived score has been classified as per below group.

Table2. Ranking of Financial performance Score

\begin{tabular}{|c|c|c|}
\hline Financial performance Scores & Category & Rank \\
\hline Above $66 \%$ & Best financial performance companies & 1 \\
\hline $57 \%-65 \%$ & Moderate financial performance companies & 2 \\
\hline Less than 56\% & Below average financial performance companies & 3 \\
\hline
\end{tabular}

Source: Computed data 
"Empirical Study on Corporate Governance Performance Index with Reference to Selected Corporate Sectors"

From the above table of financial performance score ranges, it can be categorized into three types namely, less than $56 \%$ with the indicator of below average financial performance, $57 \%$ to $65 \%$ with moderate financial performance and above $66 \%$ with best financial performance. The respective ranks are also displayed in the table.

\section{A Relationship between financial Performance and Corporate Governance PraCTICES}

After classifying both corporate governance practices and financial performance of companies, the researcher has identified 9 possible combinations to link the financial performance with corporate governance performance of the companies for better evaluation. Hence the researcher has further attempted to match the performance of companies with corporate governance index companies based on the ranking method and following are the matched cases and respective scores obtained for 9 possible combinations given in Table

Table3. Financial performance and corporate governance scores

\begin{tabular}{|c|c|c|c|}
\hline SI No & Combination & $\begin{array}{l}\text { No of Companies } \\
\text { Matched }\end{array}$ & Score \\
\hline 1 & $\begin{array}{l}\text { Best Performance companies with Best Corporate Governance Index } \\
\text { companies }\end{array}$ & 6 & $12 \%$ \\
\hline 2 & $\begin{array}{l}\text { Best Performance companies with Moderate Corporate Governance } \\
\text { companies }\end{array}$ & 4 & $8 \%$ \\
\hline 3 & $\begin{array}{l}\text { Best Performance companies with below average Corporate } \\
\text { Governance Index companies }\end{array}$ & - & - \\
\hline 4 & $\begin{array}{l}\text { Moderate Performance companies with Best Corporate Governance } \\
\text { Index companies }\end{array}$ & 12 & $24 \%$ \\
\hline 5 & $\begin{array}{l}\text { Moderate Performance companies with Moderate Corporate } \\
\text { Governance Index companies }\end{array}$ & 8 & $16 \%$ \\
\hline 6 & $\begin{array}{l}\text { Moderate Performance companies with below average Corporate } \\
\text { Governance Index companies }\end{array}$ & 2 & $4 \%$ \\
\hline 7 & $\begin{array}{l}\text { Below average Performance companies with Best Corporate } \\
\text { Governance Index companies }\end{array}$ & 4 & $8 \%$ \\
\hline 8 & $\begin{array}{l}\text { Below average Performance companies with Moderate Corporate } \\
\text { Governance Index companies }\end{array}$ & 6 & $12 \%$ \\
\hline 9 & $\begin{array}{l}\text { Below average Performance companies with below average Corporate } \\
\text { Governance Index companies }\end{array}$ & 8 & $16 \%$ \\
\hline & Overall & 50 & $100 \%$ \\
\hline
\end{tabular}

Source: Computed data

It is evident from that out of fifty companies, a maximum of percentage of $24 \%$ (12 companies) with the combinations of "moderate performance companies with best corporate governance index companies", 8 companies matched with $16 \%$ score in respect of the combination "moderate performance companies with moderate corporate governance index companies" and "Below average Performance companies with below average corporate governance index companies" and 6 companies (12\%) matched for two combinations viz., "Best Performance companies with Best Corporate Governance index companies" and "Below average Performance companies with Moderate Corporate Governance index companies". It is further noted that two groups of 4 companies each (8\%) have the combination of "Best Performance companies with Moderate Corporate Governance index companies" and "Below average Performance companies with Best Corporate Governance index companies" respectively and finally 2 companies (4\%)which has the combination of "Moderate Performance companies with below average Corporate Governance index companies". This model indicates best corporate governance practices is essential for all types of companies to have moderate to best performance. This emphasized that the corporate governance practices are very essential for the best performance of the companies. 
"Empirical Study on Corporate Governance Performance Index with Reference to Selected Corporate Sectors"

Table4. List of Sample companies with CGD score \& Financial Performance score

\begin{tabular}{|c|c|c|c|c|c|}
\hline Sl.No & Name of Company & CG Score \% & CG Rank & Financial PerformanceScore \% & $\begin{array}{c}\begin{array}{c}\text { Performance } \\
\text { Rank }\end{array} \\
\end{array}$ \\
\hline 1 & Tata Consultancy Services* & 83 & 3 & 64 & 1 \\
\hline 2 & Reliance Industries Ltd & 92 & 1 & 64 & 1 \\
\hline 3 & ITC & 88 & 2 & 61 & 1 \\
\hline 4 & Oil \& Natural Gas Corporation & 83 & 3 & 69 & 1 \\
\hline 5 & Coal India & 85 & 2 & 61 & 1 \\
\hline 6 & Infosys & 83 & 3 & 58 & 2 \\
\hline 7 & Hindustan Unilever & 90 & 1 & 61 & 1 \\
\hline 8 & Bharti Airtel & 78 & 3 & 56 & 2 \\
\hline 9 & NTPC & 86 & 2 & 56 & 2 \\
\hline 10 & Larsen \& Toubro & 82 & 3 & 53 & 2 \\
\hline 11 & Sun Pharmaceutical Industries & 81 & 3 & 50 & 3 \\
\hline 12 & Dr. Reddy's Laboratories & 79 & 3 & 50 & 3 \\
\hline 13 & Lupin & 83 & 3 & 50 & 3 \\
\hline 14 & Cipla & 83 & 3 & 50 & 3 \\
\hline 15 & Glaxo Smith Kline & 83 & 3 & 50 & 3 \\
\hline 16 & Ranbaxy Laboratories & 82 & 3 & 44 & 3 \\
\hline 17 & Cadila Healthcare & 81 & 3 & 50 & 3 \\
\hline 18 & Glenmark Pharmaceuticals & 82 & 3 & 50 & 3 \\
\hline 19 & Divis Laboratories & 81 & 3 & 50 & 3 \\
\hline 20 & Apollo Hospitals Enterprise & 79 & 3 & 50 & 3 \\
\hline 21 & Tata Motors & 88 & 2 & 53 & 2 \\
\hline 22 & Mahindra \& Mahindra & 86 & 2 & 50 & 3 \\
\hline 23 & Bajaj Auto & 82 & 3 & 58 & 2 \\
\hline 24 & Maruti Suzuki & 85 & 2 & 50 & 3 \\
\hline 25 & Hero Motocorp & 86 & 2 & 56 & 2 \\
\hline 26 & Eicher Motors & 82 & 3 & 50 & 3 \\
\hline 27 & Ashok Leyland & 83 & 3 & 47 & 3 \\
\hline 28 & Wabco India & 83 & 3 & 53 & 2 \\
\hline 29 & Amtek India & 79 & 3 & 47 & 3 \\
\hline 30 & TVS Motor & 86 & 2 & 50 & 3 \\
\hline 31 & Wipro & 79 & 3 & 50 & 3 \\
\hline 32 & HCL Technologies & 83 & 3 & 53 & 2 \\
\hline 33 & Tech Mahindra & 83 & 3 & 50 & 3 \\
\hline 34 & Mphasis & 82 & 3 & 50 & 3 \\
\hline 35 & MindTree & 83 & 3 & 50 & 3 \\
\hline 36 & Vakrangee Softwares & 85 & 2 & 50 & 3 \\
\hline 37 & Hexaware Technologies & 83 & 3 & 50 & 3 \\
\hline 38 & Infotech Enterprises (CYIENT) & 85 & 2 & 50 & 3 \\
\hline 39 & NIIT Technologies & 86 & 2 & 50 & 3 \\
\hline 40 & Zensar Technologies & 83 & 3 & 50 & 3 \\
\hline 41 & Ultratech Cement & 83 & 3 & 50 & 3 \\
\hline 42 & Hindustan Zinc & 83 & 3 & 50 & 3 \\
\hline 43 & NMDC & 83 & 3 & 50 & 3 \\
\hline 44 & Asian Paints & 82 & 3 & 53 & 2 \\
\hline 45 & BHEL & 86 & 2 & 50 & 3 \\
\hline 46 & Ambuja Cements & 86 & 2 & 50 & 3 \\
\hline 47 & $\mathrm{BOSCH}$ & 85 & 2 & 61 & 1 \\
\hline 48 & Tata Steel & 89 & 2 & 47 & 3 \\
\hline 49 & Jindal Steel \& Power & 82 & 3 & 47 & 3 \\
\hline 50 & Titan Industries & 82 & 3 & 56 & 2 \\
\hline
\end{tabular}

Source: Annual Reports \& Computed data

\section{CONCLUSION}

The effectiveness of corporate governance in difference sectors of companies depends upon the confidence building of board of $\mathrm{CG}$ and their managerial abilities in governing the corporates 
effectively. The best performance of board members leads to consistent growth of the companies which stands testimony for effectiveness of corporate governance.

The corporate governance index score among top ten companies in five different sectors classified them into high CG Index score, Moderate CG Index score and low CG Index score companies. These three differences categorized the effectiveness of CG and also indicate their financial performance in overall with respect to various corporate governance parameters. Hypothesis-1 is accepted at 5\% level and concluded that there is no significant difference in corporate governance score index of various sectors of companies. In the case of Hypothesis-2 is statistically significant at 5\% level and concluded that there is a significant difference in corporate governance score index of high corporate governance score companies. In the case of Hypothesis-3, it is found statistically significant at 5\% level and concluded that there is significant difference among the moderate corporate governance score companies. In the case of Hypothesis-4, it is found statistically insignificant at 5\% level and concluded that there is no significant difference among the low corporate governance score companies.

The researcher also validated the relationship between financial performance and corporate governance practices of top ten companies in five different sectors. It is concluded that effective CG Index is positively related to financial performance of companies.

The researcher has also identified that effective CG is $100 \%$ ensures best performance but it is not the necessary condition for ensuring best performance. The researcher proved that the best CG is only a sufficient condition for the best performance of any companies.

\section{REFERENCES}

[1] Agrawal and Knoeber (1996), cited by Chi-kun, Ho, "Corporate Governance and Corporate Competitiveness: An International Analysis," Corporate Governance: An International Review, Vol.13, No.2, March 2005, p.219.

[2] Balasubramanian, N., Corporate Boards and Governance, Sterling Publishers, U.K.,1998.

[3] Das S.C, "Ethics in Governance Practices in Corporate - Some Issues and Implications, "The Management Accountant, April 2006.

[4] Ezzamel and Watson cited by Chi-Kun, Ho, "Corporate Governance and Corporate Competitiveness: An International Analysis," Corporate Governance: An International Review, Vol.13,No.2, March 2005,p.219.

[5] Melvin, Colin and Hans Hirt. Corporate Governance and Performance, Hermes Pensions Management Ltd, London, January 2005.

[6] Nag Mohan U, "Corporate Governance - A Matter of Mindset, "The Chartered Financial Analyst, October 1996, Pp. 84-85.

[7] Nagarajan N.R, "Corporate Governance - Current Scenario in India," The Management Accountant, November 2006.

Citation: Dr. M. Sakthivel Murugan. " "Empirical Study on Corporate Governance Performance Index with Reference to Selected Corporate Sectors" International Journal of Managerial Studies and Research (IJMSR), vol 6, no. 1, 2018, pp. 1-7. doi:http://dx.doi.org/10.20431/2349-0349.0601001.

Copyright: () 2018 Authors. This is an open-access article distributed under the terms of the Creative Commons Attribution License, which permits unrestricted use, distribution, and reproduction in any medium, provided the original author and source are credited. 